Article

\title{
Polyphenolic Composition of Rosa canina, Rosa sempervivens and Pyrocantha coccinea Extracts and Assessment of Their Antioxidant Activity in Human Endothelial Cells
}

\author{
Efthalia Kerasioti ${ }^{1}$, Anna Apostolou ${ }^{2}$, Ioannis Kafantaris ${ }^{1}$, Konstantinos Chronis ${ }^{1}$, \\ Eleana Kokka ${ }^{1}$, Christina Dimitriadou ${ }^{1}$, Evangelia N. Tzanetou ${ }^{2,3}$, Alexandros Priftis ${ }^{1}$, \\ Sofia D. Koulocheri ${ }^{2}$, Serkos A. Haroutounian ${ }^{2}$ D , Demetrios Kouretas ${ }^{1}$ and Dimitrios Stagos ${ }^{1, *}$ \\ 1 Department of Biochemistry and Biotechnology, University of Thessaly, Viopolis, 41500 Larissa, Greece; \\ e-f-thalia@hotmail.com (E.K.); kafantarisioannis@gmail.com (I.K.); kochronis@uth.gr (K.C.); \\ elkokka@uth.gr (E.K.); xristina_211@hotmail.com (C.D.); priftis@uth.gr (A.P.); dkouret@uth.gr (D.K.) \\ 2 Laboratory of Nutritional Physiology and Feeding, Agricultural University of Athens, Iera Odos 75, \\ 11855 Athens, Greece; annapost21@msn.com (A.A.); eyatza@gmail.com (E.N.T.); skoul@aua.gr (S.D.K.); \\ sehar@aua.gr (S.A.H.) \\ 3 Department of Pesticides Control and Phytopharmacy, Benaki Phytopathological Institute, 8 St. Delta Street, \\ Kifissia, 14561 Athens, Greece \\ * Correspondence: stagkos@med.uth.gr; Tel.: +30-241-056-5229
}

Received: 6 March 2019; Accepted: 1 April 2019; Published: 6 April 2019

\begin{abstract}
The aim of the present study was the investigation of the antioxidant activity of plant extracts from Rosa canina, Rosa sempervivens and Pyrocantha coccinea. The results showed that the bioactive compounds found at higher concentrations were in the R. canina extract: hyperoside, astragalin, rutin, (+)-catechin and (-)-epicatechin; in the $R$. sempervirens extract: quinic acid, (+)-catechin, (-)-epicatechin, astragalin and hyperoside; and in the P. coccinea extract: hyperoside, rutin, (-)-epicatechin, (+)-catechin, astragalin, vanillin, syringic acid and chlorogenic acid. The total polyphenolic content was 290.00, 267.67 and $226.93 \mathrm{mg}$ Gallic Acid Equivalent (GAE)/g dw, and the total flavonoid content 118.56, 65.78 and $99.16 \mathrm{mg}$ Catechin Equivalent (CE)/g dw for R. caninna, $R$. sempervirens and P. coccinea extracts, respectively. The extracts exhibited radical scavenging activity in DPPH and 2,2'-azino-bis(3-ethylbenzothiazoline-6-sulphonic acid) (ABTS) $\bullet^{+}$assays and protection from ROO•-induced DNA damage in the following potency order: $R$. canina $>R$. sempervirens $>$ $P$. coccinea. Finally, treatment with $R$. canina and P. coccinea extract significantly increased the levels of the antioxidant molecule glutathione, while $R$. canina extract significantly decreased Reactive Oxygen Species (ROS) in endothelial cells. The results herein indicated that the R. canina extract in particular may be used for developing food supplements or biofunctional foods for the prevention of oxidative stress-induced pathological conditions of endothelium.
\end{abstract}

Keywords: Rosa canina; Rosa sempervivens; Pyrocantha coccinea; polyphenols; antioxidants; endothelial cells; glutathione

\section{Introduction}

It is well known that within living organisms, the reactive oxygen species (ROS) are produced endogenously under physiological processes such as metabolism and inflammation [1,2]. Low ROS levels are needed for the progression of several basic biological processes including cellular proliferation and differentiation $[2,3]$. However, excessive intracellular concentration of ROS can lead to oxidative 
stress, a pathological condition associated with the development of various of diseases including cancer, diabetes, rheumatoid arthritis and other degenerative diseases in humans [4,5]. Oxidative stress causes healthy cells of the body to lose their function and structure as a consequence of ROS interaction with proteins, lipids and DNA [6].

One of the tissues that is especially susceptible to oxidative stress is vascular endothelium, a critical regulator of vascular homeostasis. Endothelial cell injury or dysfunction by ROS can be both a cause and consequence of many vascular complications including atherosclerosis, thrombosis and cardiovascular diseases $[7,8]$. In particular, vascular endothelium cells are susceptible to ROS damage, since ROS derived from different tissues circulate in the bloodstream and can interact directly with endothelial cells in the inner wall of blood vessels $[9,10]$. In addition, oxidative stress may cause damage to the endothelium through leukocyte adhesion [11].

However, human organism possesses several antioxidant mechanisms to counteract the overproduction and harmful effects of ROS [12]. The antioxidant protective mechanisms act in order to keep a balance between free radical production and scavenging. These antioxidants are either produced endogenously or obtained through diet, especially from plant foods [13]. The antioxidant proprieties of plant foods are mainly attributed to polyphenols, a large group of secondary metabolites, that possess antiradical activities due to their phenolic hydroxyls acting as reducing agents, metal ion chelators, antioxidant enzymes activators, and oxidases inhibitors [14,15]. Thus, there is currently a great interest in natural sources of antioxidants in order to improve the redox status and protect the organism from the detrimental effects of oxidative stress.

Many plant species of the Rosaceae family are considered to be of high importance because of their use in various food preparations as jam, tea and beverages. The Rosa genus of Rosaceae family consists of approximately 200 species located mainly in the Northern hemisphere in rainy areas and deserts [16]. Rosa species produce rose hips, a pseudocarp or a fruit. A number of studies have shown that rose hips demonstrate a great variety of bioactivities such as antioxidant, anticancer, anti-inflammatory and anti-obesity activities [17-20]. Wild fruits of Rosa canina are rich in vitamin C and are used for the prevention and/or treatment of many diseases including diabetes, flu, arthritis, inflammations, pain and diarrhea $[17,18,21]$. Rosa sempervirens, the evergreen rose, is a representative member of the Rosa species. It is a thorny, climbing rose characterized by long branches with few or no prickles. Moreover, it is an important source of vitamin C, carotenoids, polyphenols, organic acids and tocopherols [22]. Pyracantha coccinea of the genus Pyracantha of the Rosaceae family is a plant growing from South Europe to South-East Asia. Its fruits are known for their rich content in fatty acids, polyphenolic compounds, phytosterols and vitamins. Thus, they have been used in traditional medicines for cardiac and diuretic properties [23].

The aim of the present study was to investigate the antioxidant properties of polyphenolic extracts derived from the following three wild Rosaceae species of Greece; Pyracantha coccinea (fruit extract), Rosa sempervirens (fruit extract) and Rosa canina (fruit extract). The extracts were initially examined for their free radical scavenging activity against DPPH• and 2,2'-azino-bis(3ethylbenzothiazoline-6-sulphonic acid) (ABTS) ${ }^{+}$radicals and for their protective effects against peroxyl (ROO•) radical-induced DNA damage. Moreover, for the first time, the ability of these extracts to enhance the antioxidant defense in human endothelial cells was assessed. As mentioned above, the oxidative stress-induced endothelium damage is a crucial etiological factor for cardiovascular diseases, and so the identification of compounds that could protect from such damage is important.

\section{Materials and Methods}

\subsection{Plant Material and Preparation of the Extracts}

Fresh plant material of the investigated Rosaceae family plants Rosa sempervirens (fruit), Rosa canina (fruit) and Pyracantha coccinea (fruit) were collected during early summer of 2014, from respective wild plants colonies that grow on Parnitha mountain (Attica Region, Greece). A voucher specimen for 
each sampling material has been deposited in the herbarium of the Agricultural University of Athens (Athens, Greece).

After air-drying, $500 \mathrm{~g}$ of each plant material were crushed, homogenized with a blender and lyophilized to provide a powder, which was stirred in darkness with $1 \mathrm{~L}$ of methanol (HPLC-analytical grade) for $48 \mathrm{~h}$. Then, the solution was filtered and the solid was re-extracted twice following the same procedure. The combined methanolic extracts $(3 \mathrm{~L}$ in total) were evaporated to dryness under reduced pressure to provide crude extracts, which were further elaborated for the assessment of their chemical content and bioactivities.

\subsection{Determination of Extracts' Polyphenolic Content Using HPLC and Ultra Performance Liquid Chromatography-Tandem Mass Spectrometer (UPLC-MS-MS) Analysis}

The chemical composition of the extracts was determined using HPLC analysis performed on a Hewlett Packard HP1100 (Hewlett Packard, Palo Alto, CA, USA) equipped with an Agilent 1100 diode-array detector (Agilent Technologies, Santa Clara, CA, USA) (measuring absorbance over the full wavelength range during the entire run), a quaternary pump, degasser and coupled to HP ChemStation utilizing the manufacturer's 5.01 software package system (Hewlett Packard, Palo Alto, CA, USA).

The column used was a Zorbax Eclipse Plus C18, $5 \mu \mathrm{m}, 150 \times 4.6 \mathrm{~mm}$ i.d. chromatographic column (Agilent Technologies, Santa Clara, CA, USA), connected with a guard column of the same material $(8 \times 4 \mathrm{~mm})$. Injection was by means of a Rheodyne injection valve (model 7725I) with a $20 \mu \mathrm{L}$ fixed loop. For the chromatographic analyses HPLC-grade water was prepared using a Milli-Q system (Merck Millipore, Burlington, MA, USA), whereas all HPLC solvents (except acetonitrile) were filtered prior to use through cellulose acetate membranes of $0.45 \mu \mathrm{m}$ pore size.

The mobile phase was composed of a gradient system of $0.3 \%$ acetic acid in water (A) and acetonitrile (B). The flow rate was maintained at $1 \mathrm{~mL} / \mathrm{min}$ and the column gradient elution program consisted of: $25 \%$ B (0 min), 25\% B (5 min), 30\% B (10 min), 40\% B (15 min), 50\% B (20 min) and $70 \% \mathrm{~B}$ (30 $\mathrm{min}$ ) where it remained for additional $5 \mathrm{~min}$, and returned during $2 \mathrm{~min}$ to initial conditions, where it stayed for additional $2 \mathrm{~min}$. This routine was followed by a $15 \mathrm{~min}$ equilibration period with the zero-time mixture prior to injection of the next sample. Prolonged runtimes (extended until $100 \mathrm{~min}$ ) were also applied to determine constituents that elute after the $35 \mathrm{~min}$ (betulinic and ursolic acids). Peaks were identified by comparing their retention times and UV-vis spectra with the reference compounds, and data were quantitated using the corresponding curves of the reference compounds as standards (Extrasynthese, Genay Cedec, France; Sigma-Aldrich, St. Louis, MO, USA; Alfa Aesar, Haverhill, MA, USA; Fluka, Buchs, Switzerland). Confirmatory UPLC-MS-MS analysis was carried out on a Thermo Scientific Ultra High Performance Liquid Chromatography system (Waltham, MA, USA) coupled to a TSQ Quantum Vantage (Thermo Fischer Scientific, San Jose, CA, USA) triple quadrupole mass spectrometer. Mass spectrometric analysis was conducted using a heated electrospray ionization (HESI) operating in two complementary modes (positive and negative mode). Selected ion monitoring (SIM) mode was primarily used to confirm the presence of analytes. In selected cases of compounds, tandem mass spectrometry (MS/MS) utilizing the multiple reaction monitoring mode (MRM) was employed for additional confirmation [quinic acid: parent ion, $\mathrm{m} / \mathrm{z} 191$ ( $\mathrm{m} / \mathrm{z} 85,93$ product ions), rutin: parent ion, $m / z 609(\mathrm{~m} / \mathrm{z} 300,271$ product ions), quercetin: parent ion, $\mathrm{m} / \mathrm{z} 300.9 \mathrm{(m} / \mathrm{z} 179,151$ product ions), quercitrin: parent ion, $\mathrm{m} / \mathrm{z} 447.1$ ( $\mathrm{m} / \mathrm{z} 301,300,271$ product ions)]. The working conditions were the following: spray voltage $4.2 \mathrm{kV}$; vaporizer and capillary temperatures 280 and $260^{\circ} \mathrm{C}$ respectively, while sheath and auxiliary gas at 60 and 40 arbitrary units respectively. The LC separation was achieved on a Hypersil Gold. $3 \mu \mathrm{m} .150 \times 3 \mathrm{~mm}$ i.d. chromatographic column (Thermo Fischer Scientific, San Jose, CA, USA). The mobile phase and the gradient system were identical to the above mentioned for the HPLC-UV analysis, using a flow rate of $0.3 \mathrm{~mL} / \mathrm{min}$. Water, acetonitrile, and acetic acid were purchased from Merck (Darmstadt, Germany) and all were LC-MS grade. PTFE filters $(0.45 \mu \mathrm{m})$ were obtained from Macherey-Nagel, Duren, Germany. All measurements were repeated three times. 


\subsection{Analytical Method Validation}

With respect to the analytical method validation part, the linearity for all analytes was determined within the ranges of 10-1000 ng/mL (using matrix matched calibration standards), demonstrating acceptable correlation coefficient values $\left(r^{2} \geq 0.99\right)$. Recovery of the investigated compounds (as a criterion of the trueness of the method) was evaluated at two concentration levels ( 40 and $200 \mathrm{ng} / \mathrm{mL}$ ) by the addition of mixed solutions of the standards into the respective extract and fell within the acceptable range of $70 \%-120 \%$. Precision values were always acceptable with percent Relative Standard Deviation $(\mathrm{RSD} \%)<15 \%$.

\subsection{Assessment of the Total Polyphenolic Content of the Extracts}

The total polyphenolic content (TPC) of the extracts was evaluated by the Folin-Ciocalteu method as described previously [24]. Briefly, $20 \mu \mathrm{L}$ of the extract were added to a tube containing $1 \mathrm{~mL}$ of deionized water. $100 \mu \mathrm{L}$ of Folin-Ciocalteu reagent was added to the reaction mixture, followed by incubation for $3 \mathrm{~min}$ at room temperature. Afterwards, $280 \mu \mathrm{L}$ of $25 \% w / v$ sodium carbonate solution and $600 \mu \mathrm{L}$ of deionized water were added to the mixture. Following $1 \mathrm{~h}$ incubation at room temperature in the dark, the absorbance was measured at $765 \mathrm{~nm}$ versus a blank containing Folin-Ciocalteu reagent and distilled water without the extract. The measurement of absorbance was conducted on a Hitachi U-1900 ratio beam spectrophotometer (Tokyo, Japan). The optical density of the sample $(20 \mu \mathrm{L})$ in $25 \% w / v$ solution of sodium carbonate $(280 \mu \mathrm{L})$ and distilled water $(1.7 \mathrm{~mL})$ at $765 \mathrm{~nm}$ was also measured. TPC was determined by a standard curve of absorbance values in correlation with standard concentrations $(50-1500 \mu \mathrm{g} / \mathrm{mL})$ of gallic acid. The total polyphenolic content was expressed as mg of gallic acid equivalents (GAE) per gram of dried weight (dw) of extract.

\subsection{Total Flavonoid Content of the Extracts}

The total flavonoid content (TFC) of the extracts was evaluated as described previously with minor changes [25]. In particular, $1 \mathrm{~mL}$ of the methanolic extract was added into a $10 \mathrm{~mL}$ flask containing $4 \mathrm{~mL}$ of deionized water. Then, $0.3 \mathrm{~mL}$ of sodium nitrite $(5 \%)$ were added to this mixture and allowed to stand for $5 \mathrm{~min}$ at room temperature. Then, $0.3 \mathrm{~mL}$ of $\mathrm{AlCl}_{3} \cdot 6 \mathrm{H}_{2} \mathrm{O}(10 \%$ ethanolic) was added, the mixture was allowed to stand for $1 \mathrm{~min}$ at room temperature and $2 \mathrm{~mL}$ of potassium hydroxide (1 M) was added. The solution was diluted to $10 \mathrm{~mL}$ with the addition of deionized water and the absorbance of the solution versus a blank at $510 \mathrm{~nm}$ was measured immediately. Flavonoid content was expressed as $\mathrm{mg}$ of catechin equivalents (CE) per gram of dry weight of extract by using a standard curve (absorbance versus concentration) prepared from authentic catechin sample.

\subsection{Free Radical Scavenging Activity}

Free radical scavenging activity of the extracts was evaluated using the 2,2-diphenyl-picrylhydrazyl

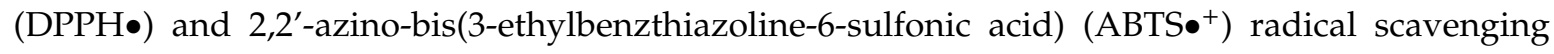
assays [26,27]. Regarding the DPPH• assay, $1.0 \mathrm{~mL}$ of freshly-made methanolic solution of DPPH• radical $(100 \mu \mathrm{M})$ was mixed with the tested extract solution at different concentrations. The contents were vigorously mixed, incubated at room temperature in the dark for $20 \mathrm{~min}$ and the absorbance was measured at $517 \mathrm{~nm}$. The measurement was conducted on a Hitachi U-1900 ratio beam spectrophotometer (Tokyo, Japan). In each experiment, the tested sample alone in methanol was used as blank and DPPH• alone in methanol was used as control. ABTS ${ }^{+}$radical scavenging activity of the extracts was determined as described previously [27] with slight modifications. Briefly, ABTS $\bullet^{+}$radical was produced by mixing $2 \mathrm{mM}$ ABTS with $30 \mu \mathrm{M} \mathrm{H}_{2} \mathrm{O}_{2}$ and $6 \mu \mathrm{M}$ horseradish peroxidase (HRP) enzyme in $1 \mathrm{~mL}$ of distilled water. The solution was vigorously mixed, incubated at room temperature in the dark for 45 min until ABTS ${ }^{+}$radical formation. Then, $10 \mu \mathrm{L}$ of different extract concentrations were added in the reaction mixture and the absorbance at $730 \mathrm{~nm}$ was read. The measurement was conducted on a Hitachi U-1900 ratio beam spectrophotometer (Tokyo, Japan). In each experiment, 
the tested sample in distilled water containing ABTS and $\mathrm{H}_{2} \mathrm{O}_{2}$ was used as blank, and the ABTS $\bullet^{+}$ radical solution with $10 \mu \mathrm{L} \mathrm{H}_{2} \mathrm{O}$ was used as control.

The percentage of radical scavenging capacity (RSC) of the tested extracts, for both assays was calculated according to the following equation:

$$
\text { Radical scavenging capacity }(\%)=\left[\left(\mathrm{A}_{\text {control }}-\mathrm{A}_{\text {sample }}\right) / \mathrm{A}_{\text {control }}\right] \times 100
$$

where $\mathrm{A}_{\text {control }}$ and $\mathrm{A}_{\text {sample }}$ are the absorbance values of the control and the tested sample respectively. Moreover, in order to compare the radical scavenging efficiency of the extracts, the $\mathrm{IC}_{50}$ value showing the concentration that caused 50\% scavenging of DPPH• and $\mathrm{ABTS}^{+}{ }^{+}$radical was calculated from the graph plotted RSC percentage against extract concentration. All experiments were carried out in triplicate and at least on two separate occasions.

\subsection{Peroxyl Radical-Induced DNA Plasmid Strand Cleavage}

The peroxyl radical-induced DNA plasmid strand cleavage assay was performed as described previously [28]. In brief, peroxyl radicals (ROO•) were produced from thermal decomposition of 2,2'-azobis(2-amidinopropane hydrochloride) (AAPH). The reaction mixture $(10 \mu \mathrm{L})$ containing $1 \mu \mathrm{g}$ Bluescript-SK+ plasmid DNA, $2.5 \mathrm{mM}$ AAPH in phosphate-buffered saline (PBS) and the tested extract at different concentrations was incubated in the dark for $45 \mathrm{~min}$ at $37^{\circ} \mathrm{C}$. Then, the reaction was stopped by the addition of $3 \mu \mathrm{L}$ loading buffer $(0.25 \%$ bromophenol blue and $30 \%$ glycerol). After analyzing the DNA samples by agarose gel electrophoresis, they were photographed and analyzed using the Alpha Innotech Multi Image (ProteinSimple, San Jose CA, USA). In addition, plasmid DNA was treated with each extract alone at the highest concentration used in the assay in order to test their effects on plasmid DNA conformation. The percentage of the protective activity of the tested extracts from ROO•-induced DNA strand breakage was calculated using the following formula:

$$
\% \text { Inhibition }=\left[\left(\mathrm{S}-\mathrm{S}_{\mathrm{o}}\right) /\left(\mathrm{S}_{\text {control }}-\mathrm{S}_{\mathrm{o}}\right)\right] \times 100
$$

where $S_{\text {control }}$ is the percentage of supercoiled DNA in the negative control sample (plasmid DNA alone), $S_{\mathrm{o}}$ is the percentage of supercoiled plasmid DNA in the positive control sample (without tested extracts but in the presence of the radical initiating factor) and $S$ is the percentage of supercoiled plasmid DNA in the sample with the tested extracts and the radical initiating factor. Moreover, $\mathrm{IC}_{50}$ values showing the concentration that inhibited the AAPH-induced relaxation by $50 \%$ were calculated from the graph plotted percentage inhibition against extract concentration. At least two independent experiments in triplicate were performed for each tested compound.

\subsection{Cell Culture Conditions}

As previously described [29], human endothelial EA.hy926 cells were cultured in normal Dulbecco's modified Eagle's medium (DMEM) in plastic disposable tissue culture flasks at $37{ }^{\circ} \mathrm{C}$ in $5 \%$ carbon dioxide.

\subsection{XTT Cell Viability Assay}

For examining the extracts' antioxidant activity in endothelial cells, non-cytotoxic concentrations were used. For selecting these concentrations, extracts' cytotoxicity in endothelial cells was checked using the XTT cell viability assay kit (Roche, Switzerland) as previously described [30]. Briefly, EA.hy926 cells were seeded into a 96-well plate with $1 \times 10^{4}$ cells per well in DMEM medium. After $24 \mathrm{~h}$ incubation, the cells were treated with different concentrations of the extracts in serum-free DMEM medium for $24 \mathrm{~h}$. Then, $50 \mu \mathrm{L}$ of XTT test solution was added to each well. After $4 \mathrm{~h}$ of incubation, absorbance was measured at $450 \mathrm{~nm}$ and also at $630 \mathrm{~nm}$ as a reference wavelength in a Bio-Tek ELx800 microplate reader (Winooski, VT, USA). The negative control was DMEM serum-free 
medium. The absorbance values of the control and samples were used for calculating the percentage inhibition of cell growth caused by the extract treatment. All experiments were carried out in triplicate and on two separate occasions.

\subsection{Treatment of EA.hy926 Cells with the Extracts}

The extracts from $R$. sempervirens, $R$. canina and P. coccinea were examined for their antioxidant capacity in endothelial EA.hy926 cells. The cells were cultured in flasks for $24 \mathrm{~h}$. Afterwards the medium was replaced with a serum-free medium containing the tested extracts at non-cytotoxic concentrations. The cells were treated with the extracts for $24 \mathrm{~h}$, and then they were trypsinized, collected and centrifuged twice at $300 \times \mathrm{g}$ for $10 \mathrm{~min}$ at $5{ }^{\circ} \mathrm{C}$. At the end of the first centrifugation, the supernatant fluid was discarded and the cellular pellet was resuspended in PBS. After the second centrifugation, the cell pellet was collected and used for measuring the glutathione (GSH) and ROS levels.

\subsection{Assessment of GSH and ROS Levels by Flow Cytometry Analysis in Endothelial Cells}

The GSH and ROS levels in EA.hy926 cells were assessed using mercury orange and DCF-DA, respectively, as described previously [31,32]. In brief, the cells were resuspended in PBS at $1 \times 10^{6}$ cells/mL and incubated in the presence of mercury orange $(10 \mu \mathrm{M})$ or $2^{\prime}, 7^{\prime}$-Dichlorofluorescin diacetate (DCF-DA) $(40 \mu \mathrm{M})$ respectively, in the dark at $37^{\circ} \mathrm{C}$ for $30 \mathrm{~min}$. Then, the cells were washed, resuspended in PBS, and submitted to flow cytometric analysis using a FACSCalibur flow cytometer (Becton Dickinson, Franklin Lakes, NJ, USA) with excitation and emission wavelengths at 488 and $530 \mathrm{~nm}$ for ROS and at 488 and $580 \mathrm{~nm}$ for GSH. Data were analyzed using 'BD Cell Quest' software (Becton Dickinson, Franklin Lakes, NJ, USA). Each experiment was repeated at least three times.

\subsection{Statistical Analysis}

All results were expressed as mean \pm SD. Differences were considered significant at $p<0.05$. One-way ANOVA was performed followed by Tukey's test for multiple pair-wise comparisons using the SPSS 20.0 software (IBM, Armonk, NY, USA).

\section{Results}

\subsection{Extract Composition in Bioactive Compounds}

The TPC values of the extracts were $267.67,290.00$ and $226.93 \mathrm{mg}$ GAE/g dw, while the TFC values were $65.78,118.56$ and $99.16 \mathrm{mg}$ CE/gr dw for $R$. sempervivens, $R$. canina and $P$. coccinea, respectively (Table 1).

Table 1. Bioactive compounds of extracts from dried fruits R. canina, R. semprevirens and P. coccinea.

\begin{tabular}{|c|c|c|c|}
\hline Compound & R. canina $^{\mathrm{a}}$ & R. semprevirens ${ }^{\text {a }}$ & P. coccinea $^{\mathrm{a}}$ \\
\hline Quinic acid & $1102.59 \pm 38.91$ & $389.95 \pm 10.29$ & ND \\
\hline$(+)$-Catechin & $134.75 \pm 1.02$ & $25.48 \pm 0.68$ & $7.93 \pm 0.31$ \\
\hline Gallic acid & $2.21 \pm 0.09$ & $0.44 \pm 0.03$ & ND \\
\hline Protocatechuic acid & $2.09 \pm 0.06$ & ND & ND \\
\hline Syringic acid & ND & ND & $6.23 \pm 0.17$ \\
\hline Caffeic acid & ND & ND & $1.49 \pm 0.08$ \\
\hline (-)-Epicatechin & $120.99 \pm 1.18$ & $34.01 \pm 0.51$ & $10.23 \pm 1.10$ \\
\hline Hyperoside & $308.11 \pm 7.10$ & $8.31 \pm 0.19$ & $170.72 \pm 3.49$ \\
\hline Rutin & $25.64 \pm 0.48$ & $2.62 \pm 0.14$ & $25.82 \pm 0.98$ \\
\hline Chlorogenic acid & ND & ND & $4.82 \pm 0.06$ \\
\hline Taxifolin & ND & ND & $0.09 \pm 0.02$ \\
\hline$p$-Coumaric acid & $2.44 \pm 0.07$ & ND & ND \\
\hline
\end{tabular}


Table 1. Cont.

\begin{tabular}{|c|c|c|c|}
\hline Compound & R. canina $^{\mathrm{a}}$ & R. semprevirens ${ }^{a}$ & P. coccinea $^{\mathrm{a}}$ \\
\hline Vanillin & ND & ND & $7.89 \pm 0.06$ \\
\hline Astragalin & $172.48 \pm 7.48$ & $9.16 \pm 0.10$ & $9.13 \pm 0.05$ \\
\hline Phloridzin & $3.41 \pm 0.10$ & ND & ND \\
\hline Eriodictyol & ND & $0.05 \pm 0.01$ & $0.06 \pm 0.01$ \\
\hline Quercitrin & ND & $0.44 \pm 0.07$ & ND \\
\hline Quercetin & $0.67 \pm 0.05$ & $0.19 \pm 0.02$ & $0.06 \pm 0.01$ \\
\hline Genistein & ND & $0.03 \pm 0.01$ & ND \\
\hline Kaempferol & $0.46 \pm 0.02$ & ND & $0.05 \pm 0.01$ \\
\hline Isorhamnetin & ND & ND & ND \\
\hline Isosakuranetin & ND & ND & $0.03 \pm 0.01$ \\
\hline Betulinic acid & $0.47 \pm 0.03$ & ND & ND \\
\hline Ursolic acid & $138.23 \pm 4.44$ & ND & ND \\
\hline $\mathrm{TPC}^{\mathrm{b}}$ & $290.00 \pm 2.10^{d}$ & $267.67 \pm 1.78^{\mathrm{e}}$ & $226.93 \pm 1.11^{f}$ \\
\hline TFC $^{\mathrm{c}}$ & $118.56 \pm 1.69 \mathrm{~g}$ & $65.78 \pm 0.93^{h}$ & $99.16 \pm 1.22^{\mathrm{i}}$ \\
\hline
\end{tabular}

ND: not detected. ${ }^{a}$ Values are expressed as $\mu \mathrm{g} / \mathrm{g}$ of dried weight of extract and are the mean \pm SD from three measurements. ${ }^{\mathrm{b}}$ TPC: Total Polyphenolic Content, expressed as $\mathrm{mg}$ of gallic acid equivalent/g dried weight extract. ${ }^{c}$ TFC: Total Flavonoid Content, expressed as $\mathrm{mg}$ of catechin equivalent/g dried weight extract. ${ }^{\mathrm{d}, \mathrm{e}, \mathrm{f}}$ Values with different superscript letters are significantly different between them $(p<0.05)$. ${ }^{\text {g,h,i }}$ Values with different superscript letters are significantly different between them $(p<0.05)$.

The results from the qualitative and quantitative assessment of the chemical composition of the extracts as assessed by using HPLC with Diode-Array Detection complemented by UPLC-MS-MS (especially for the quantitative analysis of non-UV sensistive compounds) analysis are depicted in Table 1. The HPLC analysis of the extracts identified polyphenols belonging to different subclasses of flavonoids such as flavanols (e.g., (+)-catechin and (-)-epicatechin), flavonols (e.g., hyperoside, rutin, astragalin, quercitrin, quercetin and kaempferol), flavanonols (e.g., taxifolin), flavanones (e.g., eriodictyol and isosakuranetin), isoflavones (e.g., genistein). In this respect, various polyphenolic acids were also detected such as hydroxybenzoic acids (e.g., gallic acid, syringic acid and protocatechuic acid), hydroxycinnamic acids (e.g., caffeic acid and p-coumaric acid) and the chlorogenic acid. Finally, a series of additional molecules were identified such as phloridzin and vanillin polyphenols, quinic acid and the terpenoids betulinic acid and ursolic acid. The latter compounds were detected only in R. canina extract.

Specifically, the chemical analysis showed that the $R$. canina extract is particularly rich in polyphenols hyperoside $(308.11 \mu \mathrm{g} / \mathrm{g} \mathrm{dw})$, astragalin $(172.48 \mu \mathrm{g} / \mathrm{g} \mathrm{dw}),(+)$-catechin $(134.75 \mu \mathrm{g} / \mathrm{g} \mathrm{dw})$ and (-)-epicatechin $(120.99 \mu \mathrm{g} / \mathrm{g} \mathrm{dw})$ (Table 1). Moreover, $R$. canina extract contained significant concentration of quinic acid $(1102.59 \mu \mathrm{g} / \mathrm{g} \mathrm{dw})$ and the terpenoid, ursolic acid $(138.23 \mu \mathrm{g} / \mathrm{g} \mathrm{dw})$ (Table 1). In R. sempervirens extract, the compounds identified at higher concentrations were quinic acid $(389.95 \mu \mathrm{g} / \mathrm{g} \mathrm{dw})$, and the polyphenols (-)-epicatechin $(34.01 \mu \mathrm{g} / \mathrm{g} \mathrm{dw}),(+)$-catechin $(25.48 \mu \mathrm{g} / \mathrm{g}$ $\mathrm{dw})$, astragalin $(9.16 \mu \mathrm{g} / \mathrm{g} \mathrm{dw})$, and hyperoside $(8.31 \mu \mathrm{g} / \mathrm{g} \mathrm{dw})$ (Table 1). Finally, P. coccinea extract exhibited higher concentrations of hyperoside $(170.72 \mu \mathrm{g} / \mathrm{g} \mathrm{dw})$, rutin $(25.82 \mu \mathrm{g} / \mathrm{g} \mathrm{dw}),(-)$-epicatechin $(10.23 \mu \mathrm{g} / \mathrm{g} \mathrm{dw})$, astragalin $(9.13 \mu \mathrm{g} / \mathrm{g} \mathrm{dw}),(+)$-catechin $(7.93 \mu \mathrm{g} / \mathrm{g} \mathrm{dw})$, vanillin $(7.89 \mu \mathrm{g} / \mathrm{g} \mathrm{dw})$ and syringic acid $(6.23 \mu \mathrm{g} / \mathrm{g} \mathrm{dw})$ (Table 1$)$.

\subsection{Free Radical Scavenging Activity of the Extracts}

All three of the extracts exhibited strong free radical scavenging activity. As known, the lower the $\mathrm{IC}_{50}$ value, the higher the antioxidant activity. Thus, in the DPPH assay the potency order and the $\mathrm{IC}_{50}$ values were: $R$. canina $(100 \mu \mathrm{g} / \mathrm{mL})>R$. sempervivens $(130 \mu \mathrm{g} / \mathrm{mL})>$ P. coccinea $(500 \mu \mathrm{g} / \mathrm{mL})$ (Table 2$)$. Similar order of portency was observed in $\mathrm{ABTS}^{\bullet+}$ assay; $R$. canina $(60 \mu \mathrm{g} / \mathrm{mL})>R$. sempervivens $(85 \mu \mathrm{g} / \mathrm{mL})>$ P. coccinea $(140 \mu \mathrm{g} / \mathrm{mL})$ (Table 2$)$. 
Table 2. Free radical scavenging activity against DPPH and ABTS radicals, protective activity against peroxyl radical $(\mathrm{ROO} \bullet)$-induced DNA damage of the extracts.

\begin{tabular}{llll}
\hline \multirow{2}{*}{\multicolumn{1}{c}{ Plant Extracts }} & $\mathbf{I C}_{\mathbf{5 0}}(\boldsymbol{\mu g} / \mathbf{m L})$ & \\
\cline { 2 - 4 } & $\mathbf{D P P H}^{\mathbf{a}}$ & ABTS $^{\mathbf{a}}$ & ROO $^{\mathbf{b}}$ \\
\hline Rosa sempervivens (fruit) & $130 \pm 7.8^{\mathrm{a}, *}$ & $85 \pm 10.0^{\mathrm{d}, *}$ & $570 \pm 51.3^{\mathrm{g}, *}$ \\
Rosa canina (fruit) & $100 \pm 7.0^{\mathrm{b}, *}$ & $60 \pm 6.6^{\mathrm{e}, *}$ & $530 \pm 68.9^{\mathrm{g}, *}$ \\
Pyracantha coccinea (fruit) $^{\mathrm{c}}$ & $500 \pm 40.0^{\mathrm{c}, *}$ & $140 \pm 4.2^{\mathrm{f}, *}$ & $950 \pm 47.5^{\mathrm{h}, *}$ \\
\hline
\end{tabular}

${ }^{\text {a }}$ Values are the mean \pm SD of at least two separate triplicate experiments. ${ }^{b}$ Values are the mean \pm SD from three independent experiments. ${ }^{*} p<0.05$, indicates significant difference from the control values. $\mathrm{a}, \mathrm{b}, \mathrm{c}$ Values with different superscript letters are significantly different between them $(p<0.05)$. d,e,f Values with different superscript letters are significantly different between them $(p<0.05)$. ${ }^{g, h}$ Values with different superscript letters are significantly different between them $(p<0.05)$.

Finally, all three extracts exhibited protective activity against ROO•-induced DNA plasmid breakage with $\mathrm{IC}_{50}$ values and potency order $R$. canina $(530 \mu \mathrm{g} / \mathrm{mL})>R$. sempervivens $(570 \mu \mathrm{g} / \mathrm{mL})>$ P. coccinea $(950 \mu \mathrm{g} / \mathrm{mL})$ (Table 2 and Figure 1).

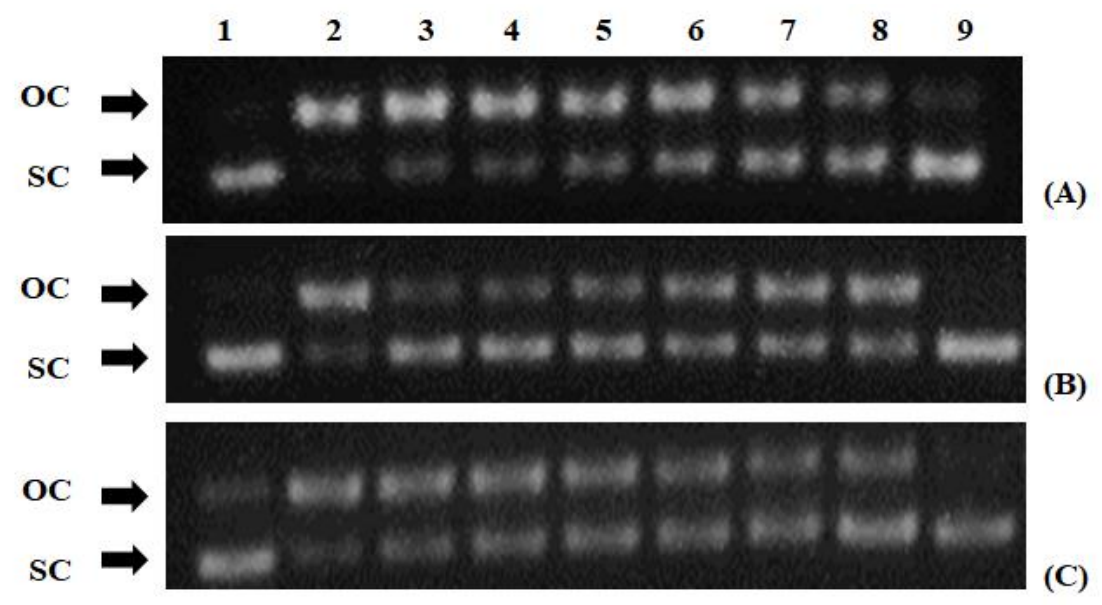

Figure 1. Protective activity of polyphenolic extracts from (A) Pyracantha coccinea, (B) Rosa sempervivens and (C) Rosa canina species against ROO• radical: Lane 1, pBluescript-SK+ plasmid DNA without any treatment; lane 2, plasmid DNA exposed to ROO• radical alone; lanes 3-8 plasmid DNA exposed to ROO• radical in the presence of different concentrations of extracts (P. coccinea: $0.063,0.125,0.250,0.500$, 1.0 and $1.5 \mathrm{mg} / \mathrm{mL}$; R. sempervivens: $2.0,1.5,1.0,0.500,0.250,0.125 \mathrm{mg} / \mathrm{mL}$; R. canina: $0.063,0.125,0.250$, 0.500, 1.0 and $1.5 \mathrm{mg} / \mathrm{mL}$ ); lane 8, plasmid DNA exposed to the maximum tested concentration of each extract alone. OC: open circular; SC: supercoiled.

\subsection{Effects of Extracts on the Antioxidant Status of Endothelial Cells}

To examine the extracts' antioxidant activity in endothelial cells, flow cytometry analysis was performed. At first, the extract's effect on cell viability was assessed using the XTT assay, in order to use non-cytotoxic concentrations. The cell viability assay showed that significant cytotoxicity was exhibited at concentrations above $2.5 \mathrm{mg} / \mathrm{mL}$ for $R$. sempervivens and $2.0 \mathrm{mg} / \mathrm{mL}$ for $R$. canina (Figure 2B,C). None of the concentrations used for P. coccinea had cytotoxicity (Figure 2A). Thus, the selected non-cytotoxic concentrations of the extracts in the following assays were up to $1.00 \mathrm{mg} / \mathrm{mL}$. 
(A)

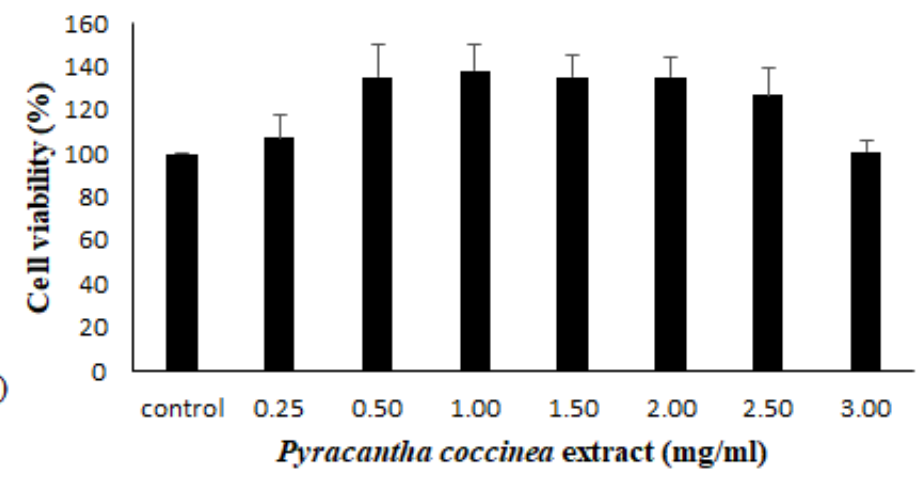

(B)

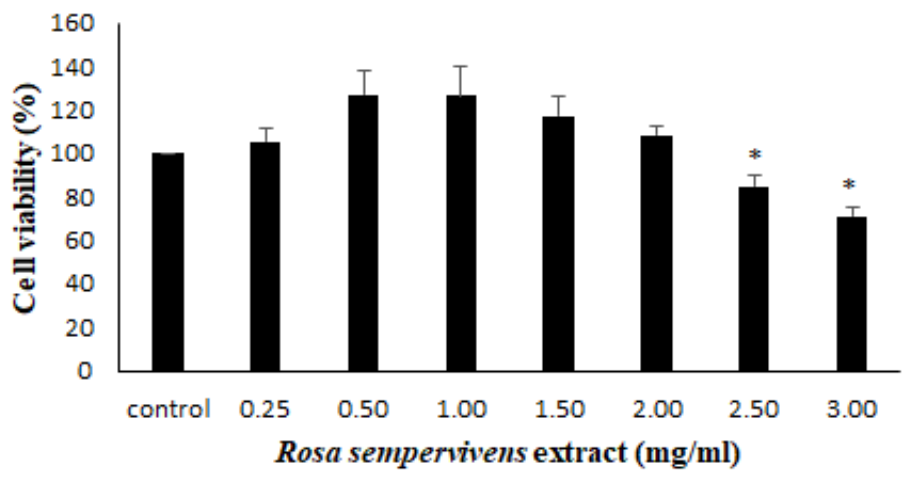

(C)

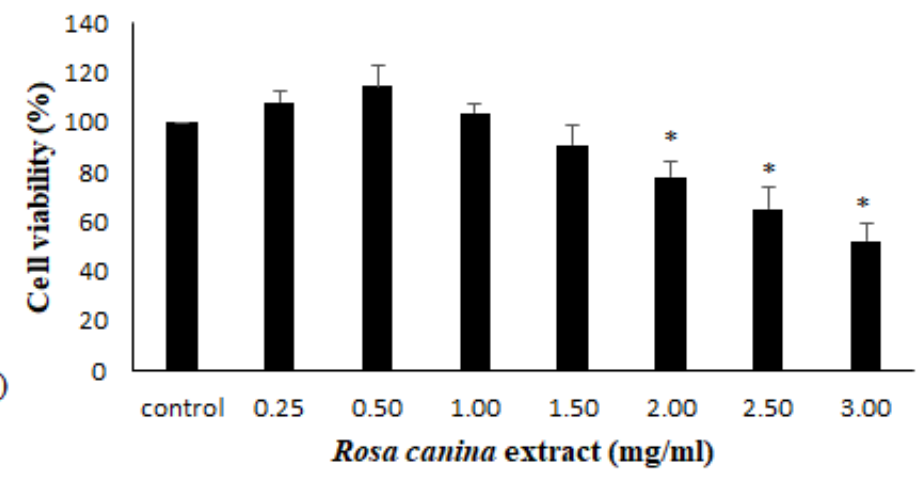

Figure 2. Cell viability following the treatment with polyphenolic extracts from (A) Pyracantha coccinea, (B) Rosa sempervivens and (C) Rosa canina species. The results are presented as the means \pm SD of three independent experiments carried out in triplicate. ${ }^{*} p<0.05$ indicates significant difference from the control value.

The assessment of the extracts' effects on the antioxidant capacity of endothelial cells was based on the measurement of GSH and ROS levels by flow cytometry analysis. The results demonstrated that R. canina extract significantly increased GSH levels by 15.0, 10.4, 28.4 and $43.1 \%$ at $0.13,0.25,0.50$ and $1.00 \mathrm{mg} / \mathrm{mL}$, respectively compared to control (Figure 3C). P. coccinea extract also significantly increased GSH levels by 29.2 and $32.3 \%$ at 0.50 and $1.00 \mathrm{mg} / \mathrm{mL}$, respectively, compared to control (Figure 3A). However, $R$. sempervirens extract did not affect GSH levels at any of the examined concentrations (Figure 3B). 
A

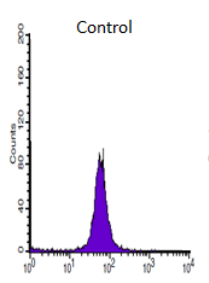

FL-2 (GSH)

B

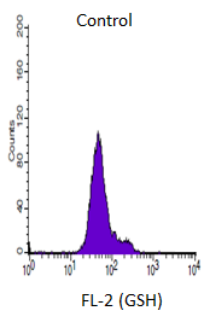

C
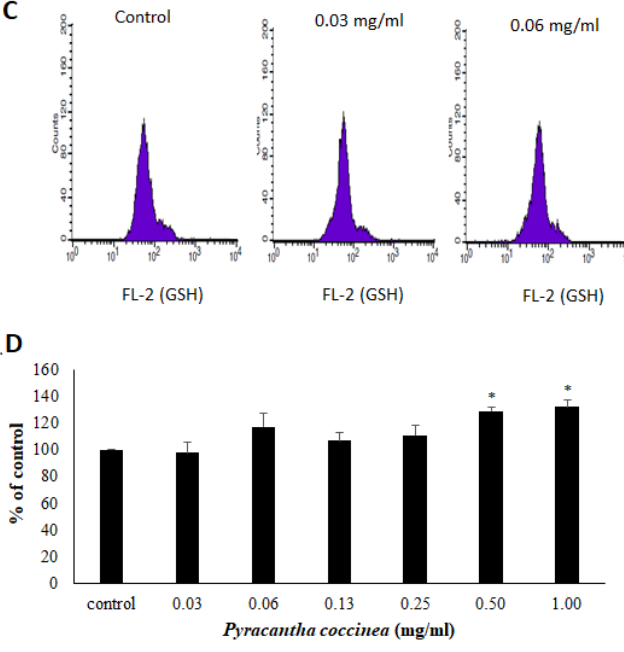

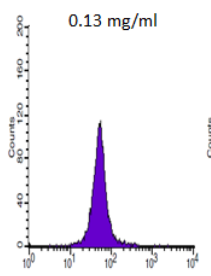

FL-2 (GSH)

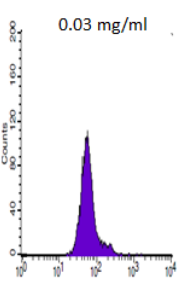

FL-2 (GSH)

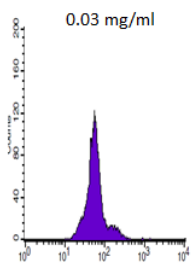

FL-2 (GSH)

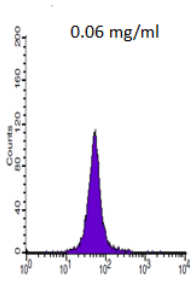

FL-2 (GSH)
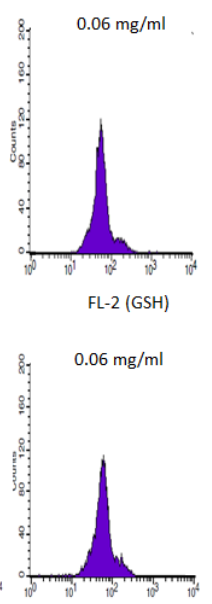

FL-2 (GSH)
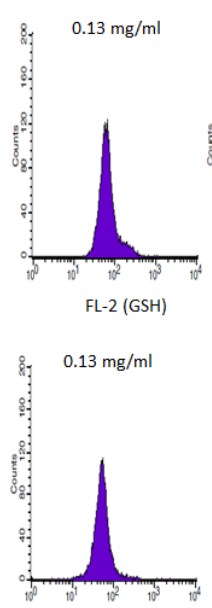
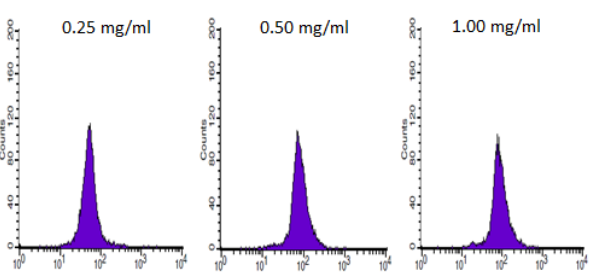

FL-2 (GSH)

FL-2 (GSH)
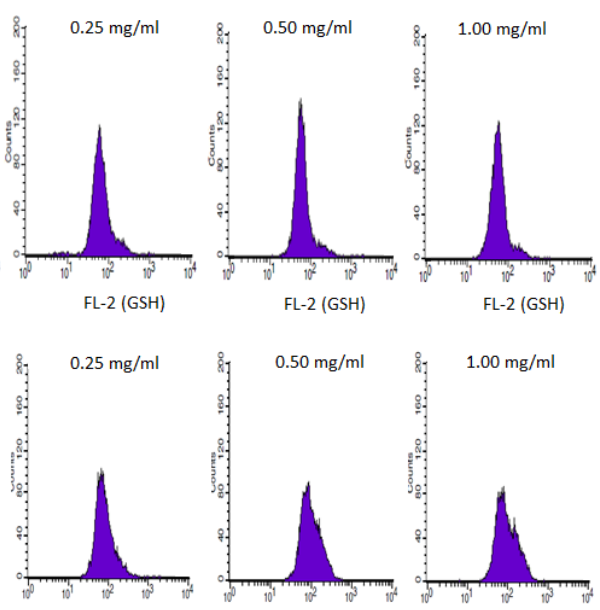

FL-2 (GSH)

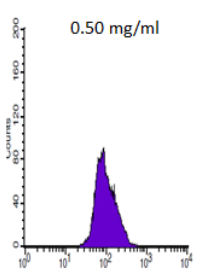

FL-2 (GSH)

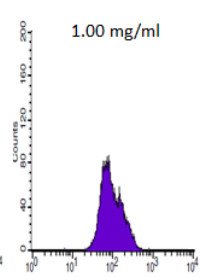

FL-2 (GSH)

E
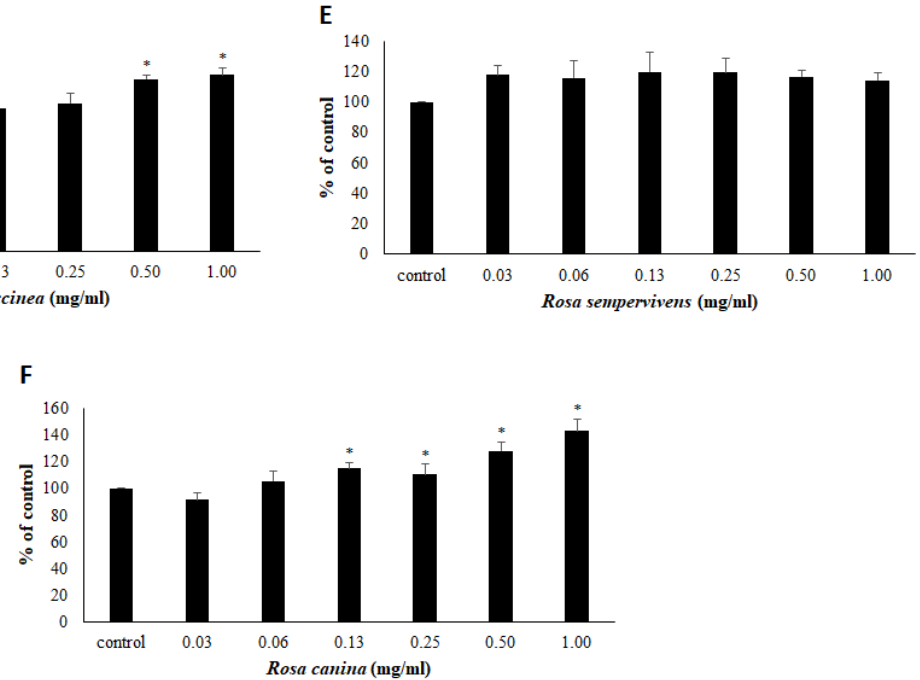

Figure 3. Effects on GSH levels after treatment with P. coccinea, $R$. sempervivens and $R$. canina extracts at different concentrations for $24 \mathrm{~h}$ in EA.hy 926 cells. The histograms of cell counts versus fluorescence of 10,000 cells analyzed by flow cytometry for the detection of GSH levels after treatment with (A) P. coccinea, (B) R. sempervivens and (C) R. canina. FL-2 represents the detection of fluorescence in the FL-2 channel using 488 and $580 \mathrm{~nm}$ as the excitation and emission wavelength, respectively. Bar charts indicate the GSH levels as \% of control as estimated by the histograms in EA.hy 926 cells after treatment with (D) P. coccinea, (E) R. sempervivens and (F) R. canina extracts. All values of bar charts are presented as the mean $\pm \mathrm{SD}$ of three independent experiments. ${ }^{*} p<0.05$ indicates significant difference from the control.

The results from the assessment of extracts' effects on ROS levels are shown in Figure 4. According to the results, only one of the three extracts affected ROS levels. In particular, $R$. canina extract significantly reduced ROS by 9.73 and $13.37 \%$ at 0.50 and $1.00 \mathrm{mg} / \mathrm{mL}$, respectively, compared to control 
(Figure 4C). However, P. coccinea and R. sempervivens extracts did not significantly affect ROS levels, compared to control (Figure 4A,B).

A
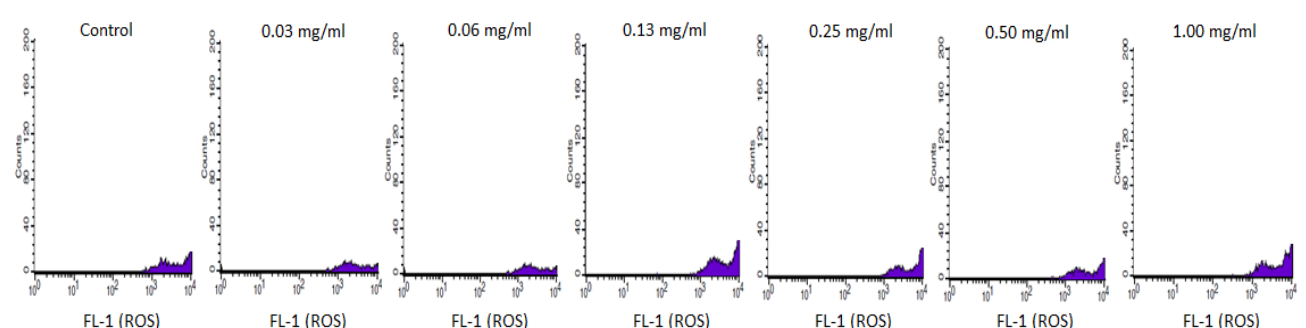

B
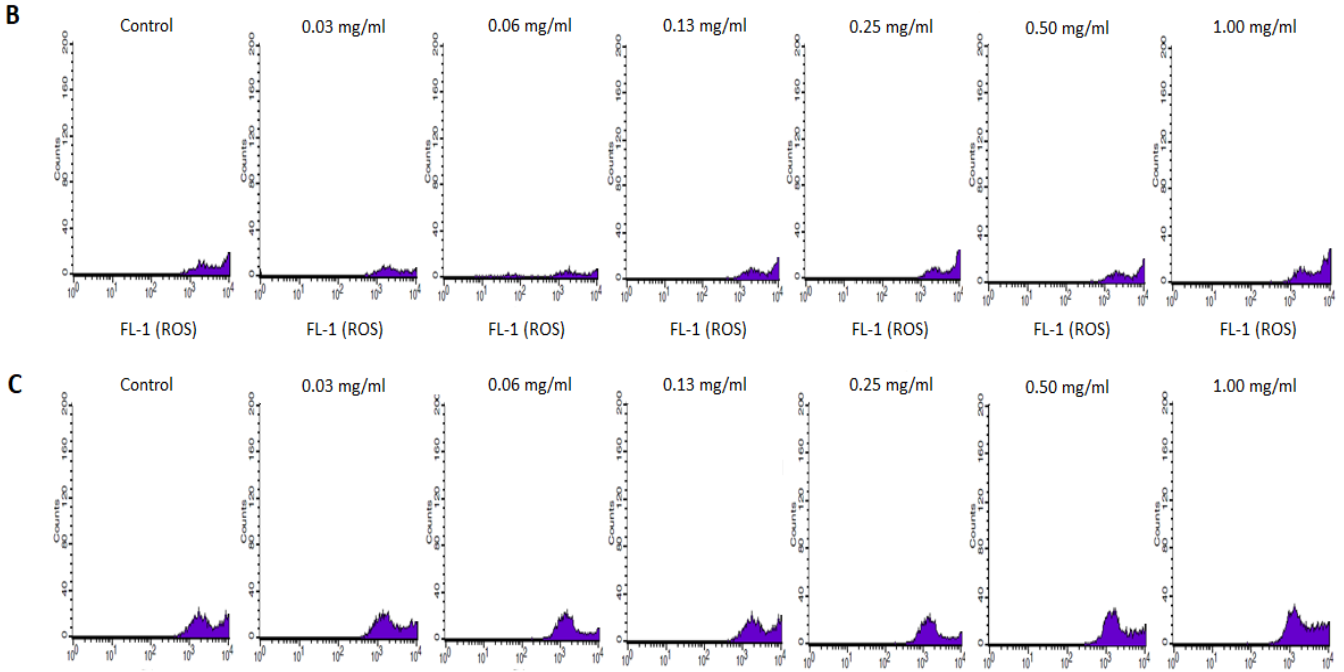

Fl-1 (ROS)

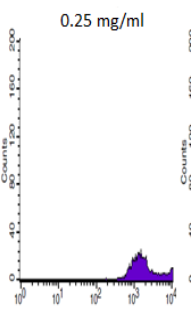

FL-1 (ROS)
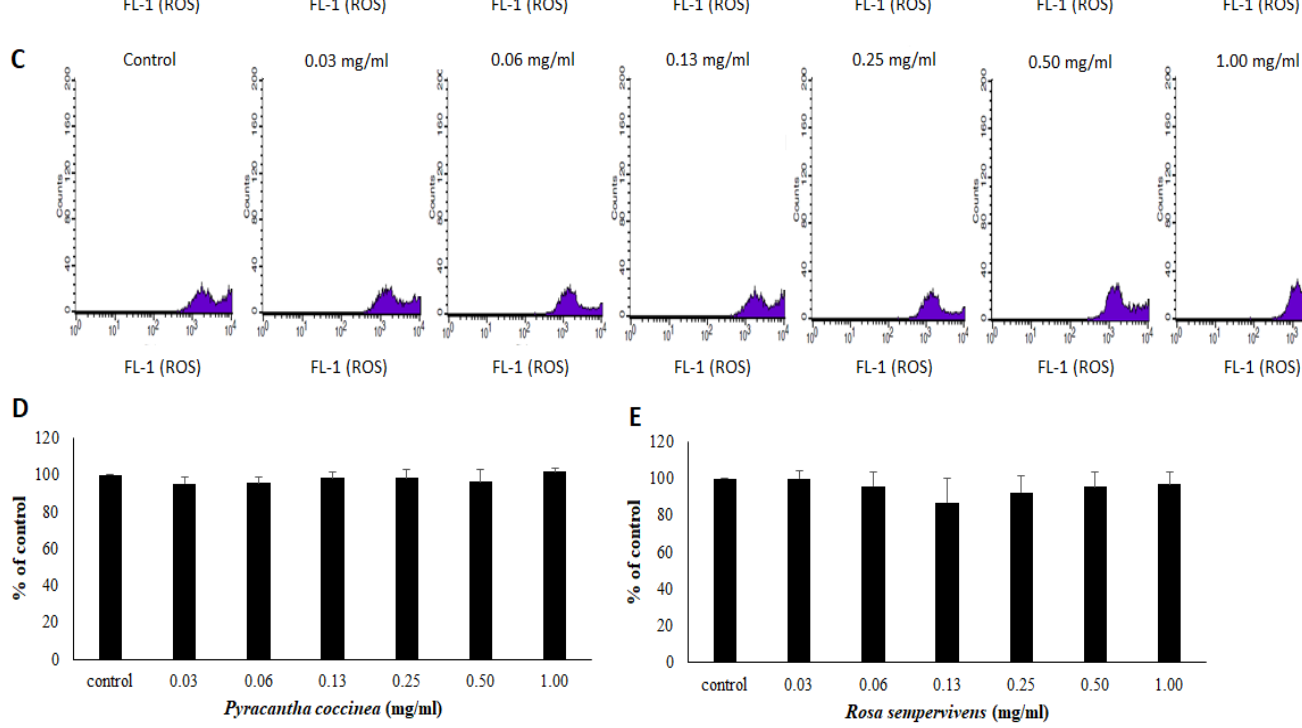

E
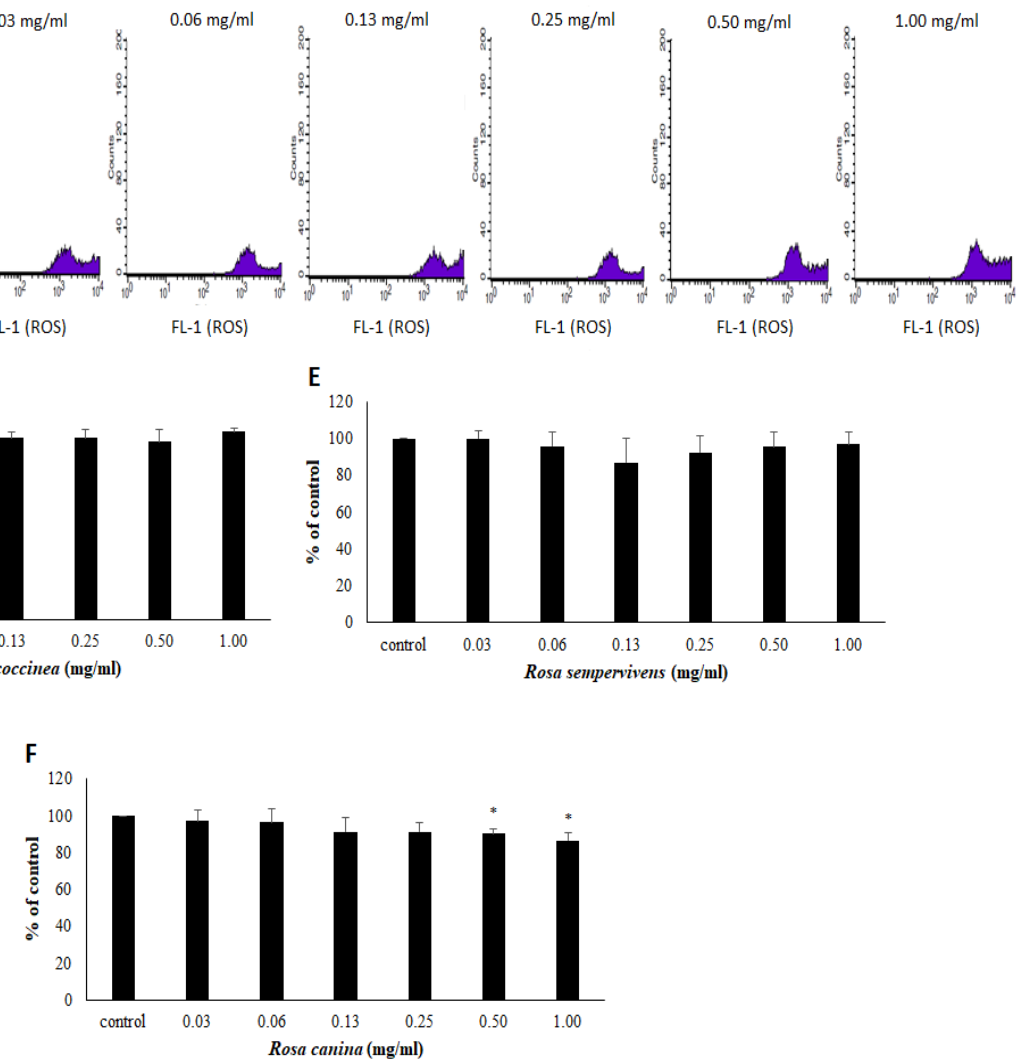

Figure 4. The diagrams show the changes in ROS levels after treatment with P. coccinea, R. sempervivens and $R$. canina extracts in EA.hy 926 cells. The histograms demonstrate the cell counts versus fluorescence of 10,000 cells analyzed by flow cytometry for the detection of ROS levels after treatment with (A) P. coccinea, (B) R. sempervivens and (C) R. canina. FL-1 represents the detection of fluorescence in the FL-1 channel using 488 and $530 \mathrm{~nm}$ as the excitation and emission wavelength, respectively. Bar charts indicate the ROS levels as \% of control as estimated by the histograms in EA.hy926 cells after treatment with (D) P. coccinea, (E) R. sempervivens and (F) R. canina extracts. All values of bar charts are presented as the mean $\pm \mathrm{SD}$ of three independent experiments. ${ }^{*} p<0.05$ indicates significant difference from the control. 


\section{Discussion}

The aim of the present study was to assess for the first time the antioxidant effects in endothelial cells of the polyphenolic extracts obtained from the fruits of three wild growing plant species, $R$. canina, $R$. sempervirens and $P$. coccinea. It should be noted that $R$. canina is a well-studied plant species [33], but there is only one study for the polyphenolic composition and the antioxidant activity of R. semprevirens fruit extracts [34] and there are only few reports for P. coccinea fruit extracts [23].

Initially, the polyphenolic composition of the extracts was analyzed. $R$. canina extract exhibited the highest TPC among the three tested extracts. So, as expected $R$. canina had also the highest TFC. However, although the $R$. sempervirens extract had higher TPC than P. coccinea, the TFC of the former was lower than that of the latter. This was probably due to the high content of the $R$. sempervirens extract in polyphenols other than flavonoids. Other studies showed that the TPC values of $R$. canina extracts were from 50 to $500 \mathrm{mg} / \mathrm{g} \mathrm{dw}$, and so our results were within this range [35,36]. There has been so far only one study on the polyphenols of $R$. sempervirens, which reported $57.9 \mathrm{mg} \mathrm{GAE} / \mathrm{g} \mathrm{dw}$ for TPC and $0.47 \mathrm{mg} \mathrm{CE} / \mathrm{g} \mathrm{dw}$ for TFC, while our values were $267.67 \mathrm{mg}$ GAE/g dw and $65.78 \mathrm{mg} \mathrm{CE} / \mathrm{g} \mathrm{dw}$, respectively [34]. Nadpal et al., [34] have used different solvents (i.e., methanol and water) for isolating polyphenolic ectracts from $R$. sempervirens. Their results showed that water extraction yielded higher TPC and TFC values compared to methanol extraction [34]. Moreover, another study demonstrated that the TPC values were different between $R$. canina extracts isolated from plants grown in different locations [36]. In a previous study, it was also shown that ethanol extracts of $R$. canina had higher TPC values than water extracts [36]. Bhave et al., [37] have also shown that the content of biologically active compounds in Rosa species depended on specific genotypes. In addition, extracts from more ripened fruits of $R$. canina have been reported to have higher TPC compared to less ripened fruits [38]. Thus, the differences between our results and those from other studies could be atrributed to different factors such as differences in the analytical methods, different extraction methods, genetic and environmental factors and the maturity stage of fruits and harvesting time [37-39].

The HPLC analysis showed that the $R$. canina extract was especially rich in the polyphenols hyperoside, astragalin, rutin, (+)-catechin and (-)-epicatechin as well as in the terpenoid ursolic acid and a poly-hydroxylated organic acid organic acid, which is the quinic acid. The presence of these compounds have also been reported in previous studies [33,40]. Moreover, several other polyphenols have been identified in trace amounts in $R$. canina extracts such as ellagic acid, salicylic acid, vanillic acid, ferulic acid and caffeic acid (not found by us) [33]. The R. sempervirens extract had higher amounts of quinic acid, (+)-catechin, (-)-epicatechin, astragalin, and hyperoside. Like our findings, Nadpal et al. (2018) [34] have also identified gallic acid, quercitrin, quercetin, hyperoside and (+)-catechin in $R$. sempervirens extract, although not at the same concentrations as our samples. However, Nadpal et al. (2018) [34] have also reported ellagic acid, protocatechuic acid (not found in our extract), ferulic acid and kaempferol-3-O-glucoside. In general, our study is the first that identified quinic acid, (-)-epicatechin, rutin, astragalin, eriodictyol, and genistein in $R$. sempervirens extract. The P. coccinea extract contained higher concentrations of hyperoside, rutin, (-)-epicatechin, (+)-catechin, astragalin, vanillin, syringic acid and chlorogenic acid. As expected, the polyphenolic profiles of the two extracts from the Rosa genus (i.e., R. canina and R. sempervirens) had more similaritities with each other than with the extract from P. coccinea of Pyracantha genus.

All three extracts exhibited strong free radical scavenging activity in DPPH and ABTS• ${ }^{+}$assays. The highest potency of the $R$. canina extract in both assays was in accordance with its highest TPC value. Some studies have reported $\mathrm{IC}_{50}$ values in DPPH assay for $R$. canina extracts, which were similar to ours, but other studies have found values that were significantly different from ours [18,40]. Previous studies have also shown that polyphenolics were the most important compounds of $R$. canina extracts for the DPPH radical scavenging activity [40]. R. sempervirens extract having higher TPC than P. coccinea extract also exhibited greater free radical scavenging activity. Nadpal et al. (2018) [34] have reported $28 \mu \mathrm{g} / \mathrm{mL}$ as $\mathrm{IC}_{50}$ value in DPPH assay for a $R$. sempervirens extract, while our value was $130 \mu \mathrm{g} / \mathrm{mL}$. 
The differences between our values and those from other studies are probably, as mentioned above, due to different factors which lead to differences in the polyphenolic composition of the extracts.

Moreover, all three extracts exerted protective activity against ROO•-induced DNA damage. Like in DPPH and ABTS $\bullet^{+}$assays, the potency order in this assay followed the order of polyphenolic concentration, that is, $R$. canina $>R$. sempervirens $>$ P. coccinea. Therefore, once again, the polyphenolic concentration seemed to play a crucial role in the protective activity from ROO•-induced DNA damage. Among the polyphenols identified in the extracts, (+)-catechin, (-)-epicatechin, rutin, vanillin, astragalin, phloridzin and gallic acid have been reported to scavenge ROO• radical [41-47]. As far as we know, protective activity of $R$. canina, $R$. sempervirens and $P$. coccinea extracts from free radical-induced DNA damage was examined for the first time in this study. Thus, based on these results, extracts from the tested plant species may be used for protection against diseases caused by ROS-induced DNA damage.

Since the tested extracts showed strong free radical scavenging activity, their antioxidant effects were also investigated at noncytotoxic concentrations in endothelial cells. Thus, the extracts' ability to increase GSH, one of the most important antioxidant molecules within cells, was assessed by flow cytometry [48]. In agreement with the free radical scavenging assays, $R$. canina extract exhibited the greatest capacity to increase GSH in the cells. However, it should be noted that when humans consumed rose hip powder from $R$. canina, there were no effects on the activity of enzymes related to GSH metabolism in erythrocytes [49]. Treatment of cells with $P$. coccinea extract also increased significantly GSH levels in EA.hy926 cells. However, R. sempervirens extract treatment had no effect on GSH levels. This finding was intriguing, since $R$. sempervirens extract contained more polyphenols than $P$. coccinea extract, while $R$. sempervirens extract's polyphenolic profile was quite similar to that of $R$. canina. This contradiction could be explained by examining the polyphenols that were found at a greater concentration in $P$. coccinea extract than in $R$. sempervirens. For example, hyperoside and rutin found at higher concentration in $R$. canina and $P$. coccinea extracts compared to $R$. sempervirens have been reported to increase GSH levels in endothelial cells $[50,51]$. The observed increase in GSH levels induced by R. canina and P. coccinea extract treatment is important, since GSH apart from its antioxidant role is a crucial regulator of cell signaling in endothelial cells [52,53].

Regarding extracts' effects on ROS levels in endothelial cells, only $R$. canina extract treatment exerted a significant decrease. This result was in accordance with $R$. canina extract's highest antioxidant potency exhibited in all the other assays. Moreover, $R$. canina extract-induced decrease in ROS levels was attributed, at least in part, to extract's capacity to increase antioxidant defense mechanisms such as GSH. Moreover, a $R$. canina extract has been shown to inhibit an $\mathrm{H}_{2} \mathrm{O}_{2}$-induced increase in ROS in colon cancer cells [54]. Furthermore, some polyphenols such as (+)-catechin, (-)-epicatechin and ursolic acid identified at higher concentrations in $R$. canina than in the other two tested extracts have been demonstrated to decrease ROS in endothelial EA.hy926 and human umbilical vein endothelial cells (HUVEC) cells [55-57].

In conclusion, the results of the present study provided new information concerning the polyphenolic composition of the tested extracts, especially those of $R$. sempervirens and $P$. coccinea fruit extracts. Moreover, all three tested extracts were demonstrated for the first time to protect against ROS-induced DNA damage, which thus suggests their possible use for prevention of relative diseases. In addition, the extracts from $R$. canina and P. coccinea were shown to increase GSH levels, the most important antioxidant molecule in endothelial cells. This finding suggests that these extracts may be used for the development of food supplements or biofunctional foods preventing diseases caused by oxidative damage to endothelium such as cardiovascular. Interestingly, previous in vivo studies have reported that administration of rose hip powder to humans or experimental animals could reduce the risk for cardiovascular diseases [22,58]. Of course, further studies are needed in order to investigate further the molecular mechanisms through which these protective activities are exerted. Moreover, since the environmental variability between different years may affect the chemical composition of the 
plant extracts and consequently their bioactivities, it should also be examined how the tested activities are changing from one year to the next.

Author Contributions: Conceptualization, D.S., S.A.H., D.K.; methodology, D.S., S.A.H., D.K.; supervision, D.S., S.A.H., D.K.; carried out the experiments, E.K. (Eleana Kokka), A.A., K.C., E.K. (Efthalia Kerasioti), C.D., E.N.T., A.P., S.D.K., I.K.; data curation, E.K. (Efthalia Kerasioti), A.P., A.A., D.S., S.A.H.; writing, D.S., S.A.H., K.C., E.K. (Eleana Kokka), C.D., I.K.; funding acquisition, D.S., S.A.H., D.K.; resources, D.S., S.A.H., D.K.; K.C., E.K. (Eleana Kokka), C.D., have contributed equally to the study.

Funding: The work was funded in part by the "Toxicology" MSc program (grant no.: 5835) in the Department of Biochemistry and Biotechnology at the University of Thessaly.

Conflicts of Interest: The authors declare no conflict of interest.

\section{References}

1. Dupre-Crochet, S.; Erard, M.; Nüße, O. ROS production in phagocytes: Why, when, and where? J. Leukoc. Biol. 2013, 94, 657-670. [CrossRef]

2. Halliwell, B. Free radicals and other reactive species in disease. In Encyclopedia of Life Sciences; Wiley, John \& Sons: London, UK, 2001; pp. 1-7.

3. Zhang, J.; Wang, X.; Vikash, V.; Ye, Q.; Wu, D.; Liu, Y.; Dong, W. ROS and ROS-Mediated Cellular Signaling. Oxid. Med. Cell Longev. 2016, 2016, e4350965. [CrossRef] [PubMed]

4. Rochette, L.; Zeller, M.; Cottin, Y.; Vergely, C. Diabetes, oxidative stress and therapeutic strategies. Biochim. Biophys. Acta 2014, 1840, 2709-2729. [CrossRef] [PubMed]

5. Lipinski, B. Pathophysiology of oxidative stress in diabetes mellitus. J. Diabetes Complic. 2001, 15, $203-210$. [CrossRef]

6. Halliwell, B. Free radicals and antioxidants: Updating a personal view. Nutr. Rev. 2012, 70, $257-265$. [CrossRef] [PubMed]

7. Deanfield, J.E.; Halcox, J.P.; Rabelink, T.J. Endothelial function and dysfunction: Testing and clinical relevance. Circulation 2007, 115, 1285-1295. [CrossRef] [PubMed]

8. Victor, V.M.; Rocha, M.; Solá, E.; Bañuls, C.; Garcia-Malpartida, K.; Hernández-Mijares, A. Oxidative stress, endothelial dysfunction and atherosclerosis. Curr. Pharm. Des. 2009, 15, 2988-3002. [CrossRef]

9. Closa, D.; Folch-Puy, E. Oxygen free radicals and the systemic inflammatory response. IUBMB Life 2004, 56, 185-191. [CrossRef]

10. Muller, M.M.; Griesmacher, A. Markers of endothelial dysfunction. Clin. Chem. Lab. Med. 2000, 38, 77-85. [CrossRef] [PubMed]

11. Zou, Y.; Yoon, S.; Jung, K.J.; Kim, C.H.; Son, T.G.; Kim, M.S.; Kim, Y.J.; Lee, J.; Yu, B.P.; Chung, H.Y. Upregulation of aortic adhesion molecules during aging. J. Gerontol. A Biol. Sci. Med. Sci. 2006, 61, 232-244. [CrossRef]

12. Karpinska, A.; Gromadzka, G. Oxidative stress and natural antioxidant mechanisms: The role in neurodegeneration. From molecular mechanisms to therapeutic strategies. Postepy Hig. Med. Dosw. 2013, 67, 43-53. [CrossRef]

13. Landete, J.M. Dietary intake of natural antioxidants: Vitamins and polyphenols. Crit. Rev. Food Sci. Nutr. 2013, 53, 706-721. [CrossRef] [PubMed]

14. Procházková, D.; Boušová, I.; Wilhelmová, N. Antioxidant and prooxidant properties of flavonoids. Fitoterapia 2011, 82, 513-523. [CrossRef] [PubMed]

15. Landete, J.M. Updated knowledge about polyphenols: Functions, bioavailability, metabolism, and health. Crit. Rev. Food Sci. Nutr. 2012, 52, 936-948. [CrossRef]

16. Jiménez, S.; Jiménez-Moreno, N.; Luquin, A.; Laguna, M.; Rodríguez-Yoldi, M.J.; Ancín-Azpilicueta, C. Chemical composition of rosehips from different Rosa species: An alternative source of antioxidants for food industry. Food Addict. Contam. Part A 2017, 34, 1121-1130. [CrossRef] [PubMed]

17. Roman, I.; Stanila, A.; Stanila, S. Bioactive compounds and antioxidant activity of Rosa canina L. Biotypes from spontaneous flora of Transylvania. Chem. Cent. J. 2013, 7, 73. [CrossRef] [PubMed]

18. Guimarães, R.; Barros, L.; Calhelha, R.C.; Carvalho, A.M.; Queiroz, M.J.R.; Ferreira, I.C. Bioactivity of different enriched phenolic extracts of wild fruits from northeastern portugal: A comparative study. Plant Foods Hum. Nutr. 2014, 69, 37-42. [CrossRef] [PubMed] 
19. Nađpal, J.D.; Lesjak, M.M.; Šibul, F.S.; Anačkov, G.T.; Četojević-Simin, D.D.; Mimica-Dukić, N.M.; Beara, I.N. Comparative study of biological activities and phytochemical composition of two rose hips and their preserves: Rosa canina L. and Rosa arvensis Huds. Food Chem. 2016, 192, 907-914. [CrossRef] [PubMed]

20. Serteser, A.; Kargioğlu, M.; Gök, V.; Bağci, Y.; Ozcan, M.M.; Arslan, D. Determination of antioxidant effects of some plant species wild growing in Turkey. Int. J. Food Sci. Nutr. 2008, 59, 643-651. [CrossRef]

21. Tumbas, V.T.; Canadanovic-Brunet, J.M.; Cetojevic-Simin, D.D.; Cetkovic, G.S.; Ethilas, S.M.; Gille, L. Effect of rosehip (Rosa canina L.) phytochemicals on stable free radicals and human cancer cells. J. Sci. Food Agric. 2012, 92, 1273-1281. [CrossRef]

22. Andersson, S.C.; Olsson, M.E.; Gustavsson, K.E.; Johansson, E.; Rumpunen, K. Tocopherols in rose hips (Rosa spp.) during ripening. J. Sci. Food Agric. 2012, 92, 2116-2121. [CrossRef] [PubMed]

23. Keser, S. Antiradical activities and phytochemical compounds of firethorn (Pyracantha coccinea) fruit extracts. Nat. Prod. Res. 2014, 28, 1789-1794. [CrossRef] [PubMed]

24. Singleton, V.L.; Orthofer, R.; Lamuela-Raventos, R. Analysis of Total Phenols and Other Oxidation Substrates and Antioxidants by Means of Folin-Ciocalteu Reagent. Methods Enzymol. 1999, 299, 152-178.

25. Jia, Z.; Tang, M.C.; Wu, J.M. The determination of flavonoid contents in mulberry and their scavenging effects on superoxide radicals. Food Chem. 1999, 64, 555-559.

26. Brand-Williams, W.; Cuvelier, M.E.; Berset, C. Use of a free radical method to evaluate antioxidant activity. LWT Food Sci. Technol. 1995, 28, 25-30. [CrossRef]

27. Cano, A.; Hernández-Ruíz, J.; García-Cánovas, F.; Acosta, M.; Arnao, M.B. An end-point method for estimation of the total antioxidant activity in plant material. Phytochem. Anal. 1998, 9, 196-202. [CrossRef]

28. Chang, S.T.; Wu, J.H.; Wang, S.Y.; Kang, P.L.; Yang, N.S.; Shyur, L.F. Antioxidant activity of extracts from Acacia confusa bark and heartwood. J. Agric. Food Chem. 2001, 49, 3420-3424. [CrossRef] [PubMed]

29. Priftis, A.; Panagiotou, E.M.; Lakis, K.; Plika, C.; Halabalaki, M.; Ntasi, G.; Veskoukis, A.S.; Stagos, D.; Skaltsounis, L.A.; Kouretas, D. Roasted and green coffee extracts show antioxidant and cytotoxic activity in myoblast and endothelial cell lines in a cell specific manner. Food Chem. Toxicol. 2018, 114, 119-127. [CrossRef] [PubMed]

30. Kerasioti, E.; Stagos, D.; Priftis, A.; Aivazidis, S.; Tsatsakis, A.M.; Hayes, A.W.; Kouretas, D. Antioxidant effects of whey protein on muscle $\mathrm{C}_{2} \mathrm{C}_{12}$ cells. Food Chem. 2014, 155, 271-278. [CrossRef] [PubMed]

31. Goutzourelas, N.; Stagos, D.; Demertzis, N.; Mavridou, P.; Karterolioti, H.; Georgadakis, S.; Kerasioti, E.; Aligiannis, N.; Skaltsounis, L.; Statiri, A.; et al. Effects of polyphenolic grape extract on the oxidative status of muscle and endothelial cells. Hum. Exp. Toxicol. 2014, 33, 1099-1112. [CrossRef]

32. Kerasioti, E.; Stagos, D.; Georgatzi, V.; Bregou, E.; Priftis, A.; Kafantaris, I.; Kouretas, D. Antioxidant Effects of Sheep Whey Protein on Endothelial Cells. Oxid. Med. Cell Longev. 2016, 2016, e6585737. [CrossRef]

33. Ayati, Z.; Amiri, M.S.; Ramezani, M.; Delshad, E.; Sahebkar, A.; Emami, S.A. Phytochemistry, traditional uses and pharmacological profile of rose hip: A review. Curr. Pharm. Des. 2018, 24, 4101-4124. [CrossRef]

34. Nađpal, J.D.; Lesjak, M.M.; Mrkonjić, Z.O.; Majkić, T.M.; Četojević-Simin, D.D.; Mimica-Dukić, N.M.; Beara, I.N. Phytochemical composition and in vitro functional properties of three wild rose hips and their traditional preserves. Food Chem. 2018, 241, 290-300. [CrossRef]

35. Gao, X.; Bjo, L.; Ttrajkovski, V.; Uggla, M. Evaluation of antioxidant activities of rosehip ethanol extracts in different test systems. J. Sci. Food Agric. 2000, 80, 2021-2027. [CrossRef]

36. Koczka, N.; Stefanovits-Banyai, E.; Ombodi, A. Total Polyphenol Content and Antioxidant Capacity of Rosehips of Some Rosa Species. Medicines 2018, 5, 84. [CrossRef]

37. Bhave, A.; Schulzova, V.; Chmelarova, H.; Mrnka, L.; Hajslova, J. Assessment of rosehips based on the content of their biologically active compounds. J. Food Drug Anal. 2017, 25, 681-690. [CrossRef]

38. Elmastas, M.; Demir, A.; Genç, N.; Dölek, Ü.; Günes, M. Changes in flavonoid and phenolic acid contents in some Rosa species during ripening. Food Chem. 2017, 25, 154-159. [CrossRef]

39. Cunja, V.; Mikulic-Petkovsek, M.; Zupan, A.; Stampar, F.; Schmitzer, V. Frost decreases content of sugars, ascorbic acid and some quercetin glycosides but stimulates selected carotenes in Rosa canina hips. J. Plant Physiol. 2015, 178, 55-63. [CrossRef]

40. Wenzig, E.M.; Widowitz, U.; Kunert, O.; Chrubasik, S.; Bucar, F.; Knauder, E.; Bauer, R. Phytochemical composition and in vitro pharmacological activity of two rose hip (Rosa canina L.) preparations. Phytomedicine 2008, 15, 826-835. [CrossRef] [PubMed] 
41. Fusi, J.; Bianchi, S.; Daniele, S.; Pellegrini, S.; Martini, C.; Galetta, F.; Giovannini, L.; Franzoni, F. An in vitro comparative study of the antioxidant activity and SIRT1 modulation of natural compounds. Biomed. Pharmacother. 2018, 101, 805-819. [CrossRef]

42. Yan, X.T.; Li, W.; Sun, Y.N.; Yang, S.Y.; Lee, S.H.; Chen, J.B.; Jang, H.D.; Kim, Y.H. Identification and biological evaluation of flavonoids from the fruits of Prunus mume. Bioorg. Med. Chem. Lett. 2014, 24, 1397-1402. [CrossRef] [PubMed]

43. Kim, G.N.; Jang, H.D. Flavonol content in the water extract of the mulberry (Morus alba L.) leaf and their antioxidant capacities. J. Food Sci. 2011, 76, C869-C873. [CrossRef] [PubMed]

44. Galano, A.; León-Carmona, J.R.; Alvarez-Idaboy, J.R. Influence of the environment on the protective effects of guaiacol derivatives against oxidative stress: Mechanisms, kinetics, and relative antioxidant activity. J. Phys. Chem. B 2012, 116, 7129-7137. [CrossRef] [PubMed]

45. Choi, J.; Kang, H.J.; Kim, S.Z.; Kwon, T.O.; Jeong, S.I.; Jang, S.I. Antioxidant effect of astragalin isolated from the leaves of Morus alba L. against free radical-induced oxidative hemolysis of human red blood cells. Arch. Pharm. Res. 2013, 36, 912-917. [CrossRef] [PubMed]

46. Vasantha Rupasinghe, H.P.; Yasmin, A. Inhibition of oxidation of aqueous emulsions of omega-3 fatty acids and fish oil by phloretin and phloridzin. Molecules 2010, 15, 251-257. [CrossRef] [PubMed]

47. Marino, T.; Galano, A.; Russo, N. Radical scavenging ability of gallic acid toward $\mathrm{OH}$ and $\mathrm{OOH}$ radicals. Reaction mechanism and rate constants from the density functional theory. J. Phys. Chem. B 2014, 118, 10380-10389. [CrossRef] [PubMed]

48. Aquilano, K.; Baldelli, S.; Ciriolo, M.R. Glutathione: New roles in redox signaling for an old antioxidant. Front. Pharmacol. 2014, 5, 196. [CrossRef]

49. Kirkeskov, B.; Christensen, R.; Bügel, S.; Bliddal, H.; Danneskiold-Samsøe, B.; Christensen, L.P.; Andersen, J.R. The effects of rose hip (Rosa canina) on plasma antioxidative activity and C-reactive protein in patients with rheumatoid arthritis and normal controls: A prospective cohort study. Phytomedicine 2011, 18, 953-958. [CrossRef]

50. Li, H.B.; Yi, X.; Gao, J.M.; Ying, X.X.; Guan, H.Q.; Li, J.C. The mechanism of hyperoside protection of ECV-304 cells against tert-butyl hydroperoxide-induced injury. Pharmacology 2008, 82, 105-113. [CrossRef]

51. Gong, G.; Qin, Y.; Huang, W.; Zhou, S.; Yang, X.; Li, D. Rutin inhibits hydrogen peroxide-induced apoptosis through regulating reactive oxygen species mediated mitochondrial dysfunction pathway in human umbilical vein endothelial cells. Eur. J. Pharmacol. 2010, 628, 27-35. [CrossRef]

52. Elliott, S.J.; Koliwad, S.K. Redox control of ion channel activity in vascular endothelial cells by glutathione. Microcirculation 1997, 4, 341-347. [CrossRef]

53. Espinosa-Díez, C.; Miguel, V.; Vallejo, S.; Sánchez, F.J.; Sandoval, E.; Blanco, E.; Cannata, P.; Peiró, C.; Sánchez-Ferrer, C.F.; Lamas, S. Role of glutathione biosynthesis in endothelial dysfunction and fibrosis. Redox Biol. 2018, 14, 88-99. [CrossRef]

54. Jiménez, S.; Gascón, S.; Luquin, A.; Laguna, M.; Ancin-Azpilicueta, C.; Rodríguez-Yoldi, M.J. Rosa canina Extracts Have Antiproliferative and Antioxidant Effects on Caco-2 Human Colon Cancer. PLoS ONE 2016, 11, e0159136.

55. Zhang, T.; Mu, Y.; Yang, M.; Al Maruf, A.; Li, P.; Li, C.; Dai, S.; Lu, J.; Dong, Q. (+)-Catechin prevents methylglyoxal-induced mitochondrial dysfunction and apoptosis in EA.hy926 cells. Arch. Physiol. Biochem. 2017, 123, 121-127. [CrossRef]

56. Ruijters, E.J.; Weseler, A.R.; Kicken, C.; Haenen, G.R.; Bast, A. The flavanol (-)-epicatechin and its metabolites protect against oxidative stress in primary endothelial cells via a direct antioxidant effect. Eur. J. Pharmacol. 2013, 715, 147-153. [CrossRef]

57. Li, Q.; Zhao, W.; Zeng, X.; Hao, Z. Ursolic Acid Attenuates Atherosclerosis in ApoE(-/-) Mice: Role of LOX-1 Mediated by ROS/NF-kB Pathway. Molecules 2018, 23, 1101. [CrossRef]

58. Cavalera, M.; Axling, U.; Rippe, C.; Swärd, K.; Holm, C. Dietary rose hip exerts antiatherosclerotic effects and increases nitric oxide-mediated dilation in ApoE-null mice. J. Nutr. Biochem. 2017, 44, 52-59. [CrossRef]

(C) 2019 by the authors. Licensee MDPI, Basel, Switzerland. This article is an open access article distributed under the terms and conditions of the Creative Commons Attribution (CC BY) license (http://creativecommons.org/licenses/by/4.0/). 